\title{
Gene expression modifications in Wharton's Jelly mesenchymal stem cells promoted by prolonged in vitro culturing
}

\author{
Valentina Gatta ${ }^{1,6+}$, Marco D'Aurora ${ }^{2,6 \dagger}$, Paola Lanuti ${ }^{3,5,6}$, Laura Pierdomenico $3,5,6$, Samantha Sperduti ${ }^{2,6}$, \\ Giandomenico Palka ${ }^{4}$, Marco Gesi ${ }^{7}$, Marco Marchisio ${ }^{3,5,6^{*}}$, Sebastiano Miscia ${ }^{3,5,6}$ and Liborio Stuppia ${ }^{1,5,6}$
}

\begin{abstract}
Background: It has been demonstrated that the umbilical cord matrix, represented by the Wharton's Jelly (WJ), contains a great number of mesenchymal stem cells (MSCs), characterized by the expression of specific MSCs markers, shared by both human and animal models. The easy access to massive WJ amount makes it an attractive source of MSCs for cell-based therapies. However, as in other stem cell models, a deeper investigation of WJderived MSCS (WJ-MSCs) biological properties, probably modulated by their prolonged expansion and fast growth abilities, is required before their use in clinical settings. In this context, in order to analyze specific gene expression modifications occurring in WJ-MSCs, along with their culture prolongation, we investigated the transcriptomic profiles of WJ-MSCs after 4 and 12 passages of in vitro expansion by microarray analysis.

Results: Hierarchical clustering analysis of the data set originated from a total of 6 experiments revealed that in vitro expansion of WJ-MSCs up to 12 passages promote selective over-expression of 157 genes and downregulation of 440 genes compared to the $4^{t} h$ passage. IPA software analysis of the biological functions related to the identified sets of genes disclosed several transcripts related to inflammatory and cell stress response, cell proliferation and maturation, and apoptosis.

Conclusions: Taken together, these modifications may lead to an impairment of both cell expansion ability and resistance to apoptosis, two hallmarks of aging cells. In conclusion, results provided by the present study suggest the need to develop novel culture protocols able to preserve stem cell plasticity.
\end{abstract}

Keywords: Wharton's Jelly, Mesenchymal stem cells, Microarray, Gene expression, In vitro expansion

\section{Background}

Mesenchymal stem cells (MSCs) are generally considered the main toolbox for cell-based therapies. Compared to embryonic stem cells (ESCs), MSCs exhibit the following advantages: accessibility with fewer ethical controversies [1], no reports of teratoma formation after transplantation, and versatile therapeutic applications [2-7]. Based on literature data, the phenotype of MSCs obtained from different sources is typically characterized

\footnotetext{
* Correspondence: m.marchisio@unich.it

${ }^{\dagger}$ Equal contributors

${ }^{3}$ Department of Medicine and Aging Science, School of Medicine and Health Sciences, University "G. d'Annunzio" Chieti-Pescara, via dei Vestini 31, 66013, Chieti, Italy

${ }^{5}$ StemTeCh Group, via Polacchi 13,66013, Chieti, Italy

Full list of author information is available at the end of the article
}

by the expression of CD44, CD73, CD90 and CD105, representing the best suited markers currently used to characterize these cells, together with the lack of the expression of endothelial/hematopoietic markers (CD144, CD34, CD45) $[8,9]$. The umbilical cord (UC) is an extraembryonic formation essential to provide feeding to the fetus during the intrauterine development. It has been shown that UC matrix, represented by the Wharton's Jelly (WJ), surrounding umbilical vessels, contains a great number of mesenchymal cells, which have been characterized as expressing aforementioned markers, shared by MSCs in both human and animal models [10-12]. The abundant amount of WJ makes it an attractive source of MSCs for cell-based therapies $[13,14]$. However, as in other stem cell models, a deep

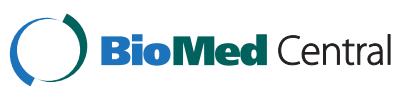


investigation of WJ-MSCs biological properties is required before their use in clinical settings. In this context, a critical point is represented by the analysis of functional modifications affecting WJ-MSCs along with their prolonged in vitro cultures. In fact, a recent study highlighted the changes in protein expression profiling, along with the in vitro expansion of WJ-MSCs, probably related to the gradual impairment of their stem cell plasticity and of the biological mechanisms occurring in cellular aging [15]. In order to provide a different investigation model of the biological modifications occurring during WJ-MSCs in vitro growth, we analyzed the transcriptomic profile of the aforementioned cells following prolonged culture times $\left[12^{\text {th }}\right.$ passage compared to an early $\left(4^{\text {th }}\right)$ passage] by microarray analysis. The aim of the present study was to identify possible novel markers related to their in vitro prolonged expansion and to their fast growth abilities.

\section{Methods}

\section{Cell isolation and culture}

Institutional review board approval was obtained for all cell culture procedures. Fresh human UC $(\mathrm{N}=5)$ were obtained from full-term births, after written informed consent was obtained from parents. UC were aseptically stored in sterile saline solution and processed within 6 hours from the partum to obtain WJ-MSCs, as previously described [15]. Briefly, after the removal of blood vessels, the extracellular matrix of WJ was scraped off, treated with $2 \mathrm{mg} / \mathrm{ml}$ collagenase IV (Sigma) for 16 hours at $37^{\circ} \mathrm{C}$ and then with $2.5 \%$ trypsin for 30 minutes at $37^{\circ} \mathrm{C}$, under agitation. Finally, the obtained cell suspension was seeded in complete Human mesenchymal stem cell growth medium (hMSCGM, Lonza) and cultured in 5\% $\mathrm{CO}_{2}$ in a $37^{\circ} \mathrm{C}$ incubator. When $80 \%$ of confluence was reached, the adherent fraction of cells was detached with $0.05 \%$ trypsin-EDTA, counted by Trypan Blue exclusion test, and reseeded at 3000 cells $/ \mathrm{cm}^{2}$ to reach the $90 \%$ of confluence after 3-4 population doublings.

\section{Immunophenotype}

WJ-MSCs were harvested at two experimental time points $\left(4^{\text {th }}\right.$ and $12^{\text {th }}$ culture passages) and were immediately incubated with $1 \mu \mathrm{g} / 10^{6}$ cells of fluorescein isotiocynate (FITC)-conjugated or phycoerythryne (PE)conjugated antibody for 40 minutes at $4{ }^{\circ} \mathrm{C}$ in the dark. Anti-CD73, anti-CD13, anti-CD90, anti-CD117, antiCD14, anti-CD34, anti-CD105 and anti-CD45 (Becton Dickinson, San Jose, CA, USA), anti-CD29, anti-CD44 and anti-CD166 (Ancell, Bayport, MN, USA) antibodies were used. After a washing step, 10,000 events/sample were acquired on a FACSCalibur flow cytometer (twolasers, four-color configuration) with CellQuest 3.2.1.f1 (BD) software; data were analysed using Flow $\mathrm{Jo}^{\text {тм }}$ software (TreeStar, Ashland, OR) [16].

\section{Doubling time and cell cycle analyses by bromodeoxyuridine incorporation assay}

Exponentially growing WJ-MSCs were exposed to $10 \mu \mathrm{M}$ bromodeoxyuridine (BrdU) (Sigma, St. Louis, MO, USA) for $1 \mathrm{~h}$, then fixed in $70 \%$ ethanol and kept at $4^{\circ} \mathrm{C}$ before labeling as previously described [17]. To detect BrdU incorporation, cells were washed with $\mathrm{PBS}$ and treated with $1 \mathrm{ml}$ of a solution containing $2 \mathrm{~N} \mathrm{HCl} / 0.5 \%$ Triton X-100 (Sigma) for $30 \mathrm{~min}$ at room temperature. $1 \mathrm{ml}$ per sample of $0.1 \mathrm{M} \mathrm{Na}_{2} \mathrm{~B}_{4} \mathrm{O}_{7}$ ( $\mathrm{pH}$ 8.57) was added to stop the $\mathrm{HCl}$ reaction. Cells were then washed with $1 \mathrm{ml}$ of a solution containing $0.5 \%$ Triton X-100/1\% BSA, followed by an incubation for $30 \mathrm{~min}$ at room temperature in the dark with fluorescein isothiocyanate (FITC)-conjugated anti-BrdU antibody (BD Biosciences, San Jose, CA; dilution: 1:5 in $0.5 \% \mathrm{v} / \mathrm{v}$ Triton X-100). Cells were washed and resuspended in a solution containing $5 \mu \mathrm{g} / \mathrm{ml}$ Propidium Iodide (PI, Sigma) and $200 \mu \mathrm{g} / \mathrm{ml}$ RNase (Sigma). After $30 \mathrm{~min}$ of incubation biparametric BrdU/DNA data were acquired on a FACSCalibur flow cytometer (two-lasers, four-color configuration) with CellQuest 3.2.1.f1 (BD) software; data were analysed using FlowJo $^{\text {тm }}$ software (TreeStar, Ashland, OR) or ModFit LT ${ }^{\mathrm{TM}}$ software (Verity Software House, Toshan, ME, USA). Debris was excluded from the analysis by gating a forward scatter versus side scatter plot. Cell aggregates were excluded by gating FL2 area versus FL2 width [17].

\section{Telomere length assay}

Genomic DNA was extracted from WJ-MSC at different passages using Wizard Genomic DNA Purification Kit (Promega) following the manufacturer's instructions. The length of telomere regions was assessed using the Telo TAGGG kit (Roche) according to the manufacturer's instructions. Appropriate controls, represented by DNA extracted from cells with long or short telomere regions, were also provided with the kit [15].

\section{Determination of cell senescence}

The amount of senescent cells was evaluated in the different reported conditions by using the Senescence $\beta$ Galactosidase Staining Kit (Abcam, Cambridge, UK) in accordance to the manufacturer's instructions, as previously described [15].

\section{Adipogenic differentiation}

To induce adipocyte differentiation, $10 \times 10^{3}$ cells $/ \mathrm{cm}^{2}$ were cultured in DMEM high glucose (HG) (Sigma) supplemented with 10\% FBS (Gibco), $0.5 \mathrm{mM}$ isobutylmethylxantine (Sigma), $200 \mu \mathrm{M}$ indomethacin (Sigma), $1 \mu \mathrm{M}$ dexamethasone (Sigma) and $10 \mu \mathrm{g} / \mathrm{ml}$ insulin (Sigma). Cells were cultured, replacing the medium every 2-3 days. After 2-3 weeks of culture, cells contained neutral lipids in fat vacuoles; they were fixed 
in $10 \%$ formalin and stained with fresh oil red-O solution (Sigma) [15].

\section{Osteogenic differentiation}

To induce osteogenic differentiation, $3 \times 10^{3}$ cells $/ \mathrm{cm}^{2}$ were cultured in MEM (Sigma) supplemented with 10\% FBS (Gibco), $10 \mathrm{mM} \beta$-glycerophosphate (Sigma), $0.2 \mathrm{mM}$ ascorbic acid (Sigma), and $10 \mathrm{nM}$ dexamethasone (Sigma), and cultured for 3-4 weeks, replacing the medium every 2-3 days. To demonstrate osteogenic differentiation, cultures were fixed and induced to the alkaline phosphatase reaction [15].

\section{Expression profiling}

Total RNA was extracted from about $10^{6}$ cells/sample of two different WJ-MSCs cultures after 4 and 12 passages during their in vitro expansion, using the SVtotal RNA Izolation System kit (Promega, Madison, WI, USA). The purity and quantity of RNA was assessed using the Agilent 8453 Spectrophotometer (Agilent, Santa Clara, CA, USA). RNA quality was determined by both the evaluation of the rRNA band integrity, using agarose electrophoresis, and absorption readings at 260 and $280 \mathrm{~nm}$. Extracted RNA was linearly amplified using the Amino AllylMessageAmp ${ }^{\mathrm{rm}}$ II aRNA Amplification Kit (Ambion, Austin, TX, USA). Five to ten $\mu \mathrm{g}$ of amplified aRNA were fluorescently labeled with Cy3-Cy5 cyanins and then hybridized on high-density array Human Whole Genome OneArray ${ }^{\text {Ts }}$ Microarray V5 (30,968 total probe; Biosense, Italy). Amplified aRNAs were used for microarray experiments carried out by hybridization of WJ-MSCs after 4 passages, compared to WJ-MSCs after 12 passages, for a total of 6 experiments (Table 1). The same biological samples have been compared at 4th and 12th passage. After hybridization, Cy3-Cy5 fluorescent signals were captured by a Confocal Laser Scanner "ScanArray Express" (Packard BioScience) and analyzed using the software "ScanArray Express-MicroArray Analysis System" version 3.0 (Perkin Elmer). Raw data of the performed experiments were recorded in the GEO public database (accession number: GSE34929). The values of the median signal intensity from each spot were subtracted from the local median background intensity. For each slide, after local background subtraction, a LOWESS algorithm was used for row data normalization, to evaluate signal to noise ratio and generate log ratios of sample $v s$ reference signal. A gene was considered to be differentially expressed when showing an absolute value of log-ratio higher or equal to \pm 0.5 , an index that translates to a fold-change of 1.4 in transcript quantity. Analysis of data obtained by microarray experiments was carried out by means of hierarchical gene clustering [18] using Cluster 3.0 (open source 2006) and TreeView (Stanford University Labs) software. In order
Table 1 Phenotype and markers expression levels in $\mathrm{WJ}$ MSC at $4^{\text {th }}$ and $12^{\text {th }}$ passage

\begin{tabular}{|c|c|c|c|c|}
\hline \multirow[t]{2}{*}{ Antigens } & \multirow[t]{2}{*}{ Phenotype } & $4^{\text {th }}$ passage & $12^{\text {th }}$ passage & \multirow[t]{2}{*}{$\mathrm{p}<$} \\
\hline & & \multicolumn{2}{|c|}{ MFI ratio \pm S.D. } & \\
\hline CD13 & + & $11.6 \pm 0.8$ & $7.7 \pm 0.8$ & 0.002 \\
\hline CD14 & - & $1.3 \pm 0.1$ & $1.1 \pm 0.1$ & 0.222 \\
\hline CD29 & +++ & $154.6 \pm 7.3$ & $141.9 \pm 2.4$ & 0.036 \\
\hline CD34 & - & $1.3 \pm 0.1$ & $1.1 \pm 0.1$ & 0.210 \\
\hline CD44 & +++ & $173.8 \pm 20.1$ & $82.0 \pm 8.7$ & 0.009 \\
\hline CD45 & - & $1.1 \pm 0.2$ & $1.2 \pm 0.2$ & 0.308 \\
\hline CD73 & ++ & $49.5 \pm 2.7$ & $19.9 \pm 1.1$ & 0.001 \\
\hline CD90 & ++ & $78.4 \pm 2.6$ & $81.0 \pm 3.2$ & 0.226 \\
\hline CD105 & + & $8.7 \pm 0.7$ & $7.9 \pm 0.5$ & 0.218 \\
\hline CD117 & - & $1.8 \pm 0.2$ & $1.5 \pm 0.2$ & 0.152 \\
\hline CD133 & - & $1.5 \pm 0.1$ & $1.2 \pm 0.1$ & 0.094 \\
\hline CD144 & - & $1.2 \pm 0.1$ & $1.3 \pm 0.2$ & 0.320 \\
\hline CD146 & + & $10.5 \pm 0.6$ & $11.3 \pm 0.6$ & 0.230 \\
\hline CD166 & + & $14.4 \pm 0.9$ & $6.8 \pm 1.2$ & 0.014 \\
\hline CD326 & - & 1. $1 \pm 0.1$ & $1.1 \pm 0.1$ & 0.420 \\
\hline HLA-ABC & + & $24.0 \pm 0.4$ & $24.9 \pm 0.6$ & 0.023 \\
\hline HLA-DR & - & $1.3 \pm 0.1$ & $1.1 \pm 0.1$ & 0.341 \\
\hline
\end{tabular}

- negative expression; + moderate expression; ++ positive; +++ high expression; MFI Ratio is the average of five different biological samples \pm standard deviation; Bold values represent MFI Ratio With $\mathrm{p}<0.01$; Cut-off positivity MFI Ratio $>2$

to include in clustering analysis only well measured transcripts, we selected spots with a present call (identified transcripts with measurable expression) in at least $80 \%$ of experiments and being $>1.7$ fold up- or down regulated in at least 5 experiments. Identified clusters were then analyzed by the Ingenuity Pathways Analysis (IPA) software (Ingenuity Systems, Redwood City, CA), in order to classify genes based on their biological functions and disclose functional networks connecting specific genes. IPA infers and ranks networks by a score, expressed as a numerical value, which is a probabilistic fit between the amount of focus genes that are potentially eligible for a network composition and present on a given gene list, the size of the network, as well as all the molecules present in the Ingenuity Knowledge Base that can be part of such a network. To validate the microarray results, qRT-PCR analysis was performed on three down-regulated (p53, HSPE1 and HIST1H3C) and three up-regulated genes (IL1B, CREBBP and LYN) as evidenced by microarray experiments, using the housekeeping gene GAPDH as internal control to normalize the relative expressions of target genes. The quantitative RT-PCR was carried out in a total volume of $50 \mu \mathrm{l}$ containing $1 \times$ TaqMan Universal PCR Master mix, no AmpErase UNG and $2 \mu \mathrm{l}$ of cDNA using the TaqMan assay on the Abi 7900 HT Sequencing Detection System. 

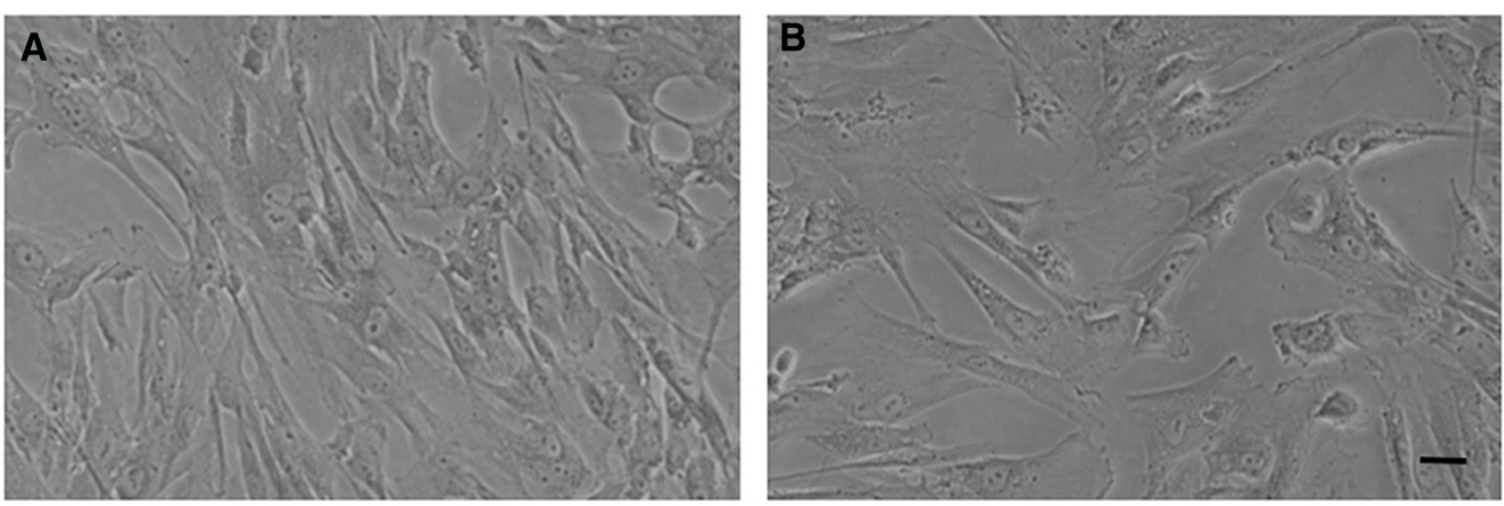

\section{C}
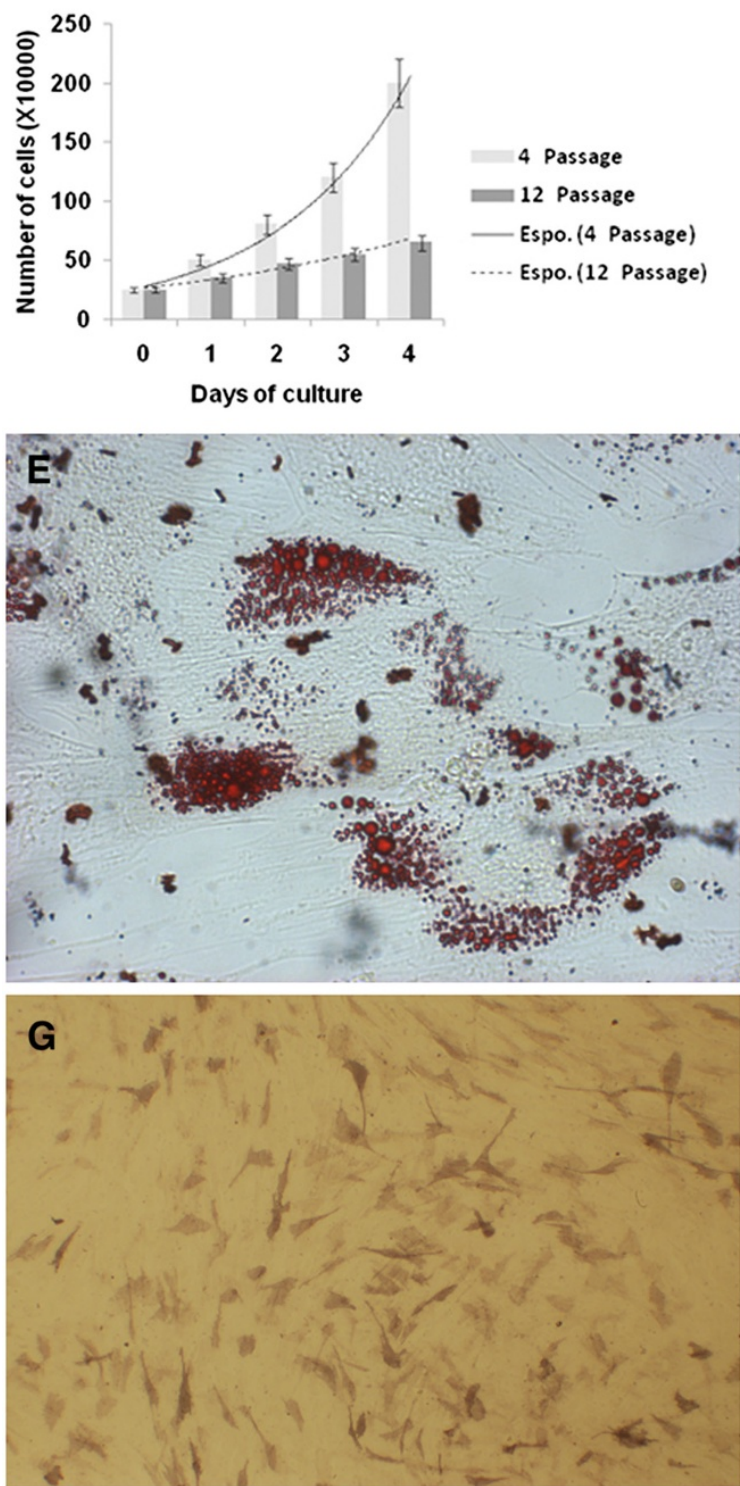

\section{D}
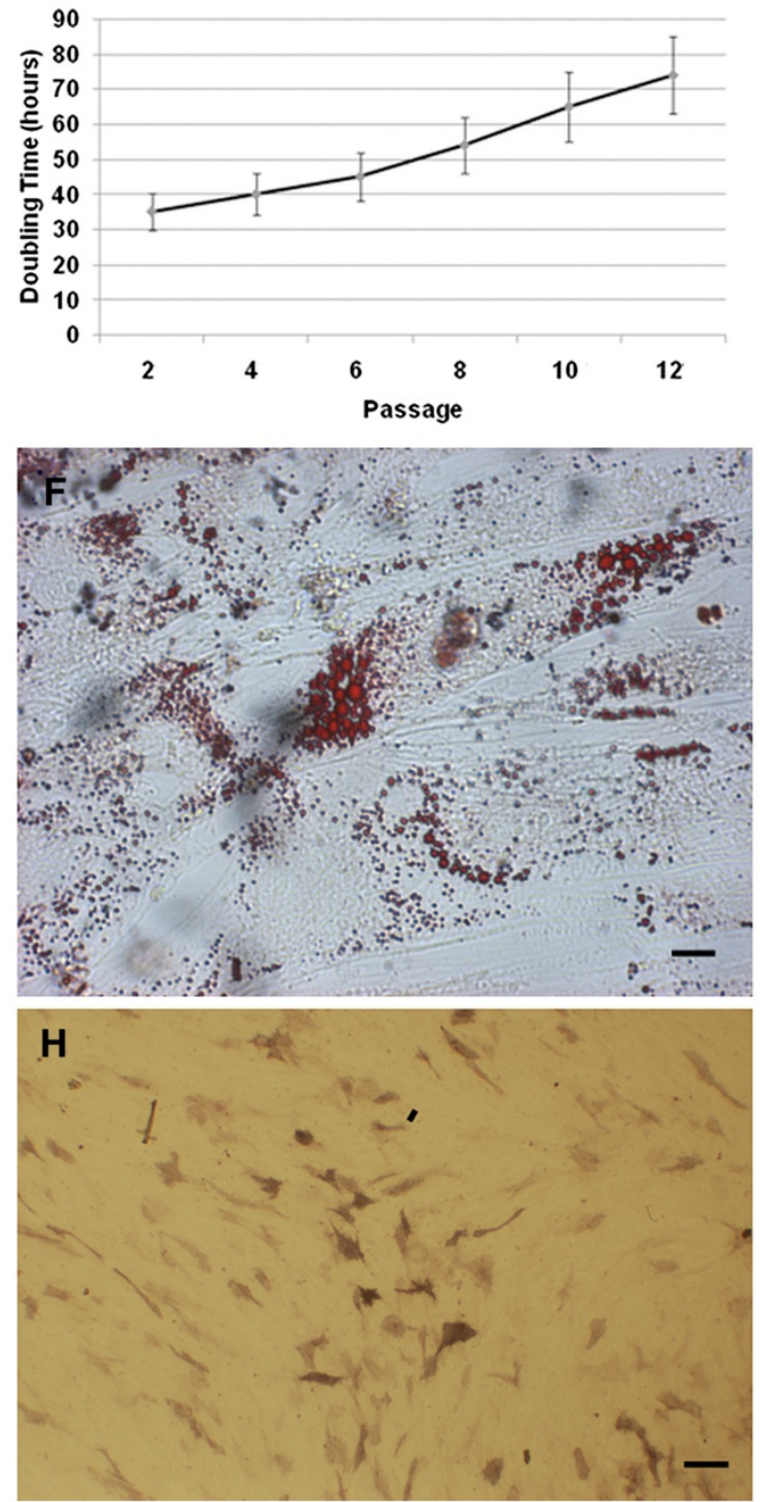

Figure 1 (See legend on next page.) 
(See figure on previous page.)

Figure 1 WJCs characterization. Light microscopic micrographs of WJ-MSCs in monolayer at the $4^{\text {th }}(\mathbf{A})$ and the $12^{\text {th }}(\mathbf{B})$ culture passages. In monolayer culture, cells assumed a polymorphic, fibroblast-like morphology, which was maintained throughout the time of culture (scale bar $40 \mathrm{Mm}$ ). Growth characterization of WJ-MSCs during the in vitro expansion ( ${ }^{\text {th }}$ and $12^{\text {th }}$ passage) measured by cell count (C) and by the BrdU incorporation assay, allowing the doubling time evaluation (D). The ability of WJ-MSCs to differentiate into the adipogenic lineage at the $4^{\text {th }}$ (E) and the $12^{\text {th }}(\mathbf{F})$ culture passages was evidenced by the intracellular accumulation of neutral lipid vacuoles (red oil staining) (scale bar $20 \mu m$ ). Osteogenic differentiation at the $4^{\text {th }}(\mathbf{G})$ and the $12^{\text {th }} \mathbf{( H )}$ culture passages was indicated by the increase in alkaline phosphatase reaction (scale bar $80 \mu \mathrm{m}$ ). Light microscopic micrographs A, B, E, F, G and $\mathrm{H}$ are representative of five separate biological samples.

Genes primers and probe sets used were NM_000546 (p53), NM_002157 (HSPE1), NM_003531 (HIST1H3C), NM_004380 (CREBBP), NM_000877 (IL1B), NM_002350 (LYN), NM_002046 (GAPDH) (Integrated DNA Technologies, Coralville, Iowa, USA). The real time amplifications included 10 minutes at $95^{\circ} \mathrm{C}$, followed by 48 cycles of 15 seconds at $95^{\circ} \mathrm{C}$ and 1 minute at $60^{\circ} \mathrm{C}$. Relative expression levels were calculated for each sample after normalization against the housekeeping gene GAPDH, using the $\Delta \Delta \mathrm{Ct}$ method for comparing relative fold expression differences [19].

\section{Results}

Cells isolation, culturing and characterization

Cells isolated from the human WJ displayed a consistent spindle-shaped elongated fibroblast-like morphology at the $4^{\text {th }}$ passage, a feature retained up to the $12^{\text {th }}$ passage (Figure 1A, B). A representative immunophenotype of cells used in our experiments is reported in Additional file 1: Figure S1. A positive response pattern expression of CD13, CD29, CD44, CD73, CD90, CD105, CD146, CD166, HLA$\mathrm{ABC}$ markers and a negative reactivity for CD14, CD34, CD45, CD117, CD133, CD144, CD326, HLA-DR were detected at both $4^{\text {th }}$ and $12^{\text {th }}$ passages (Table 1 ). Such a high homogeneous marker expression suggests that nonstem cell populations did not significantly contaminate samples used in the present study. On the other hand, the expression of CD13, CD44 and CD73 underwent a progressive and statistically significant reduction at the $12^{\text {th }}$ passage (Table 1) while the variation of the adhesion molecule expression (CD14, CD44 and CD73) is in accordance with a stem cell aging process, during in vitro expansion. The steady ability of WJ-MSCs to differentiate into both adipogenic and osteogenic lineages at the $4^{\text {th }}$ and the $12^{\text {th }}$ passage was evidenced (Figure 1). After their expansion, cells showed a homogeneous diploid content during the G1 cell-cycle phase (Additional file 2: Figure S2). Furthermore, G1 and G2 cell-cycle checkpoints appeared intact. This finding is consistent with actively cycling cells. The long telomeric end of DNA extracted from WJ-MSCs at all examined passages also confirms that these cells preserve their capability to undergo a high number of cellular divisions up to the $12^{\text {th }}$ passage (data not shown) [15]. Accordingly, a low frequency of cells staining positive for $\beta$ galactosidase was found at both studied passages $\left(4^{\text {th }}\right.$ and $\left.12^{\text {th }}\right)$. On the other hand, long-term in vitro culture passages led to an impairment of cell expansion ability, as demonstrated by different exponential curves of growth at the $4^{\text {th }}$ and the $12^{\text {th }}$ passage, as demonstrated by cell counts (Figure 1C). These data were confirmed by the analysis of the doubling time obtained through the BrdU incorporation assay, associated to the DNA staining (Figure 1D): results evidenced that the doubling time progressively increased from $32 \mathrm{~h}$ at the $4^{\text {th }}$ passage to $74 \mathrm{~h}$ at the $12^{\text {th }}$ passage $(\mathrm{p}<0.001)$.

\section{Gene expression profile of WJ-MSCs at the $4^{\text {th }}$ passage vs the $12^{\text {th }}$ passage}

To gain insights on the global changes in gene expression of human WJ-MSCs, produced by 12 passages in vitro expansion as compared to 4 passages, we performed a hierarchical clustering analysis of the data set originated from a total of 6 experiments (3 biological and 3 technical replicates). On a total of 30,968 transcripts investigated by the array, the analysis revealed that 12 passages in vitro expansion of WJ-MSCs promote the selective over-expression of 157 genes (cluster 1), while 440 genes were downregulated (cluster 2) as compared to 4 passages expansion cells (Figure 2; Additional file 3: Table S1; Additional file 4: Table S2). Ingenuity Pathway Analysis (IPA) was carried out to investigate the main functions played by the selected clusters of genes. The up-regulated gene dataset $(n=157)$ was mainly composed by genes involved in functions regarding cellular development, cellular growth and proliferation, cellular movement, cell death, cellular assembly and organization, gene expression, cancer, cellular compromise, nervous system development and function, cell cycle, cell morphology, post-translational modifications and RNA post-transcriptional modification (Figure 3A). This analysis also demonstrated that down-regulated genes $(n=440)$ were involved in functions regarding cell cycle, cancer, nervous system development and function, cell morphology, protein synthesis, cell death, cell signaling, cellular growth and proliferation, cellular movement, post-translational modification and free radical scavenging (Figure 4A).

\section{Networks associated with transcripts selectively modified at the $12^{\text {th }}$ passage in vitro expansion}

IPA software predicts functional networks based on known protein-protein and functional interactions. We 


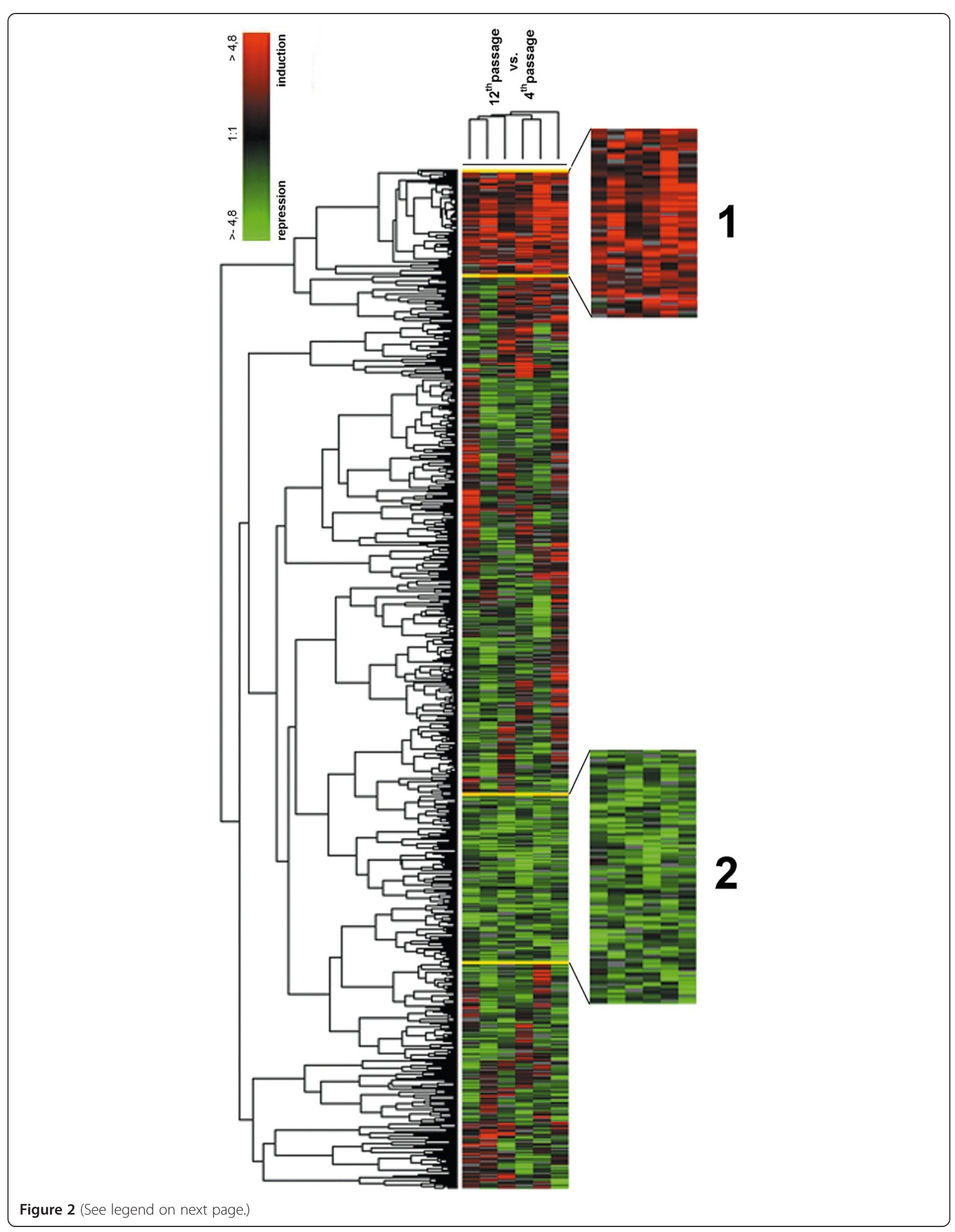


(See figure on previous page.)

Figure 2 Hierarchical clustering analysis. The cluster analysis shows the presence of two different clusters composed respectively by 157 upregulated transcripts (cluster 1) and 440 down-regulated genes (cluster 2). In the figure, all the relevant genes are grouped according to their expression values, shown as log ratios. Each row corresponds to one gene, each column to the different 6 microarray experiments. The quantitative changes in gene expression across all the samples are represented in different colors: red indicates over-expressed genes, and green indicates down-regulated genes. Black bars indicate no changes in gene expression. Missing data points are represented as gray bars. The top labels indicate the different experiments.

therefore employed IPA to study how the genes selectively changing their expression at the $12^{\text {th }}$ passage as compared to the $4^{\text {th }}$ passage were interacting in specific networks.

IPA analysis of the up-regulated genes indicated 8 networks with a score ranging from 46 to 16 . The first top network generated by IPA (score $=46$ ) (Figure 3B) is composed by: i) genes around the gene node IL1, namely IL1B, IL1R1, S100113 and TWIST2, that participate in the inflammatory response and apoptosis; ii) genes around AKT gene node, namely RAC2 and PTPRF, involved in protein phosphorylation, cell differentiation, proliferation and maturation; iii) other genes not linked to any specific node, whose function is related to the transcription regulation (PARP1, HNRNPAB, NONO CREBBP), cytoskeletal organization (ACTR3, NISCH), MSC differentiation (EPHA4, MT2A, CDH2, RAC), cell stress response (ERRFI1), inhibition of apoptosis (RNF7, TWIST2, IL1B), cell proliferation and maturation (LYN) (Table 2). IPA analysis of the down-regulated genes showed 14 networks with a score ranging from 45 to 11 . The first top network generated by IPA (score $=45$ ) (Figure 4B) is composed by: i) genes around p53 gene node, namely UBE2D3, MAP2K3, ZHX1, XPO1, PIN1, CDC27, ANAPC2; ii) other genes not linked to any specific node, whose function was related to cell proliferation and pluripotency (TYMS, FGFR3, MITF and NCAPD2), oxidative stress (RPS3, NFE2L2, HSP1, HAT1), NF-kB signaling (IKBKG, MYL5), apoptosis (SLC6A4, TPH1) and histone modification (HAT1, HIST1H3C) (Table 3).

\section{TaqMan Real Time quantitative PCR and western blot: validation of the microarray data}

qRT-PCR analysis, performed in order to validate microarray data by investigating three down-regulated ( $\mathrm{p} 53$, HSPE1 and HIST1H3C) and three up-regulated genes (IL1B, CREBBP and LYN) present in the first top up and down gene networks, respectively, (Figure 5) and western blot analysis of p53, HIST1H3C and IL1B protein (Additional file 5: Figure S3; Additional file 6: Western Blot Method), confirmed the results obtained by the microarray analysis.

\section{Discussion}

It is well known that during cell culture different kind of stem cells can undergo functional modifications related to the number of culture passages $[70,71]$. The identification of these modifications is of crucial relevance in order to better understand the biology of stem cells and the differences in their ability to proliferate and differentiate, along with cell expansion. The study of the whole stem cell transcriptome, carried out by microarray technology, allows to identify the global changes occurring in the expression profiles of these cells, providing useful information about their functional changes along with culture progression. In the present study, we carried out an analysis of gene expression profiles of WJ-MSCs at $4^{\text {th }}$ and $12^{\text {th }}$ passages, in order to evidence the modifications in the trascriptome induced by the culture time prolongation. IPA gene analysis revealed that the top upregulated network was characterized by the presence of 2 independent functional nodes (IL1, AKT). IL1 node is connected with IL1B, IL1R1, S100113 and TWIST2 genes, related to inflammation. The up regulation of these genes in older cells could reflect the presence of an inflammation cellular response acting as a defense mechanism of damaged cells for preventing cell death. AKT node, connected with RAC2 and PTPRF genes, is involved in protein phosphorylation, regulating cellular growth and differentiation, and their over expression appears to be mainly related to cell differentiation and maturation [25]. Other up-regulated genes in this network, although not related to any evident node, are anyway worth of interest due to their specific functions. Among these, four genes (CREBBP, PARP1, HNRNPAB, $\mathrm{NONO}$ ) are well known to be involved in the regulation of transcription and play an important role in various cellular processes such as differentiation and proliferation [30,32]. In particular, CREBBP gene is critical in embryonic neural development [29] and HNRNPAB gene, interacting with Oct4, is involved in embryonic stem cells differentiation [31]. On the other hand, cytoskeleton organization is the main function played by the other two genes present in the network, complex Arp2/ 3 and Nischarin (ACTR3, NISCH). In the top upregulated network are also presents 3 genes (EPHA4, MT2A, CDH2) representing neural marker related to MSC differentiation. Interestingly, the contemporary activation of RAC2 and $\mathrm{CDH} 2$ has been reported as related to MSC differentiation [37]. The last three genes with interesting function detected in this network are ERRFI1, RNF7 and LYN. The up-regulation of these 

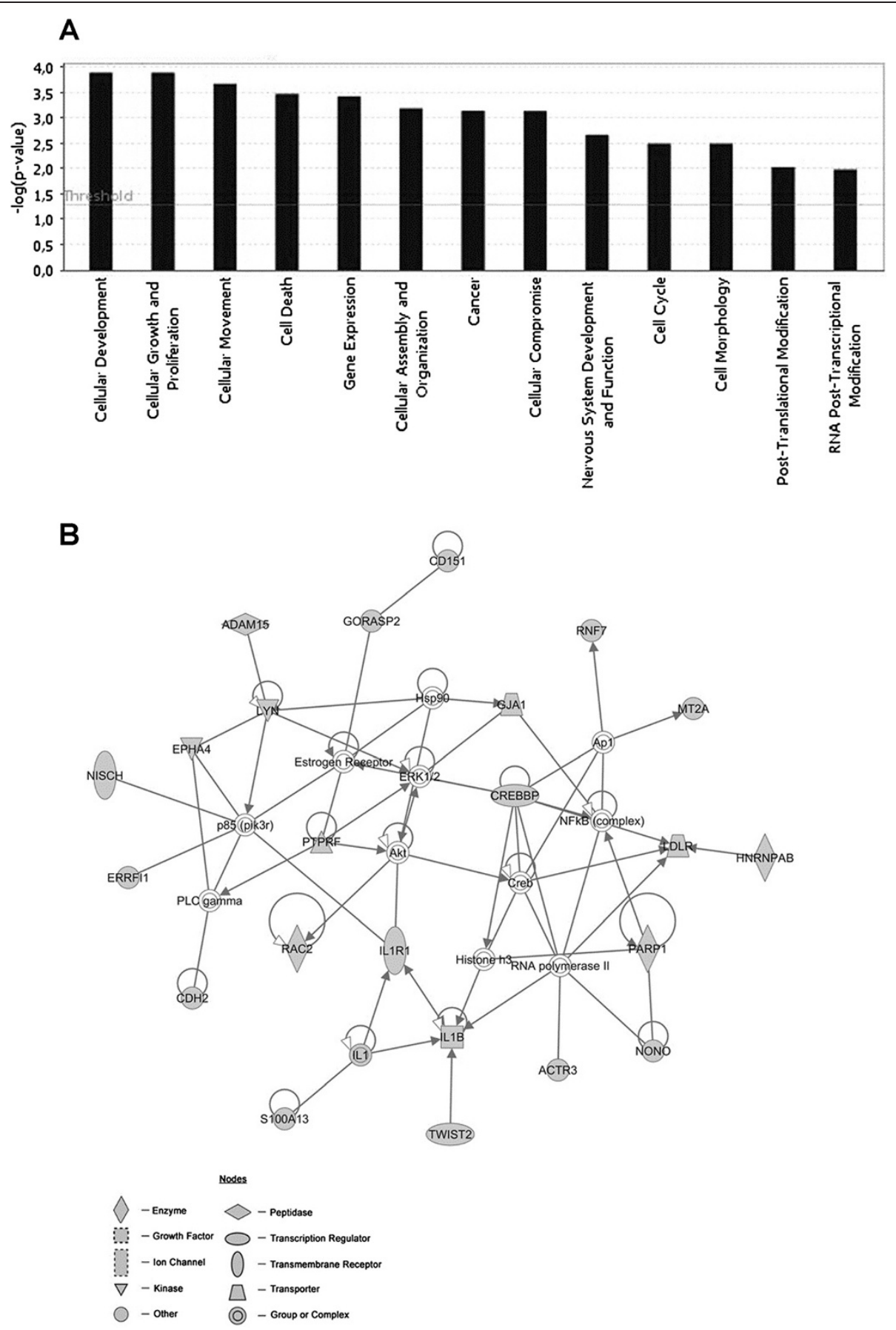

Figure 3 IPA functional analysis and first top network associated with the Cluster 1. (A) Bar chart shows key function associated with genes found to be up-regulated (cluster 1) in WJ-MSCS after 12 passages of their in vitro expansion, as compared to WJ-MSCS at the $4^{\text {th }}$ passage. (B) Network cluster 1: in grey are represented the genes up-regulated in WJ-MSCs after 12 passages of their in vitro expansion, as compared to WJ-MSCs at the $4^{\text {th }}$ passage. Transcripts not modulated along with the different passages are represented in white. Arrows indicate that a molecule acts on another molecule, while lines indicate a bind between two molecules.

genes is associated with cell growth and proliferation [40] and ERRFI1 activity is induced during cell stress $[38,72]$. RNF7 has an antiapoptotic activity mediated by the activation of the transcription factor JUN [39]. Among the down-regulated gene network, the most interesting node is centered around the TP53 gene, encoding for the major suppressor protein that can recognize DNA damage and subsequently arrest the cell cycle and trigger the repair process. It has been reported that TP53 functional activity is reduced during the aging 

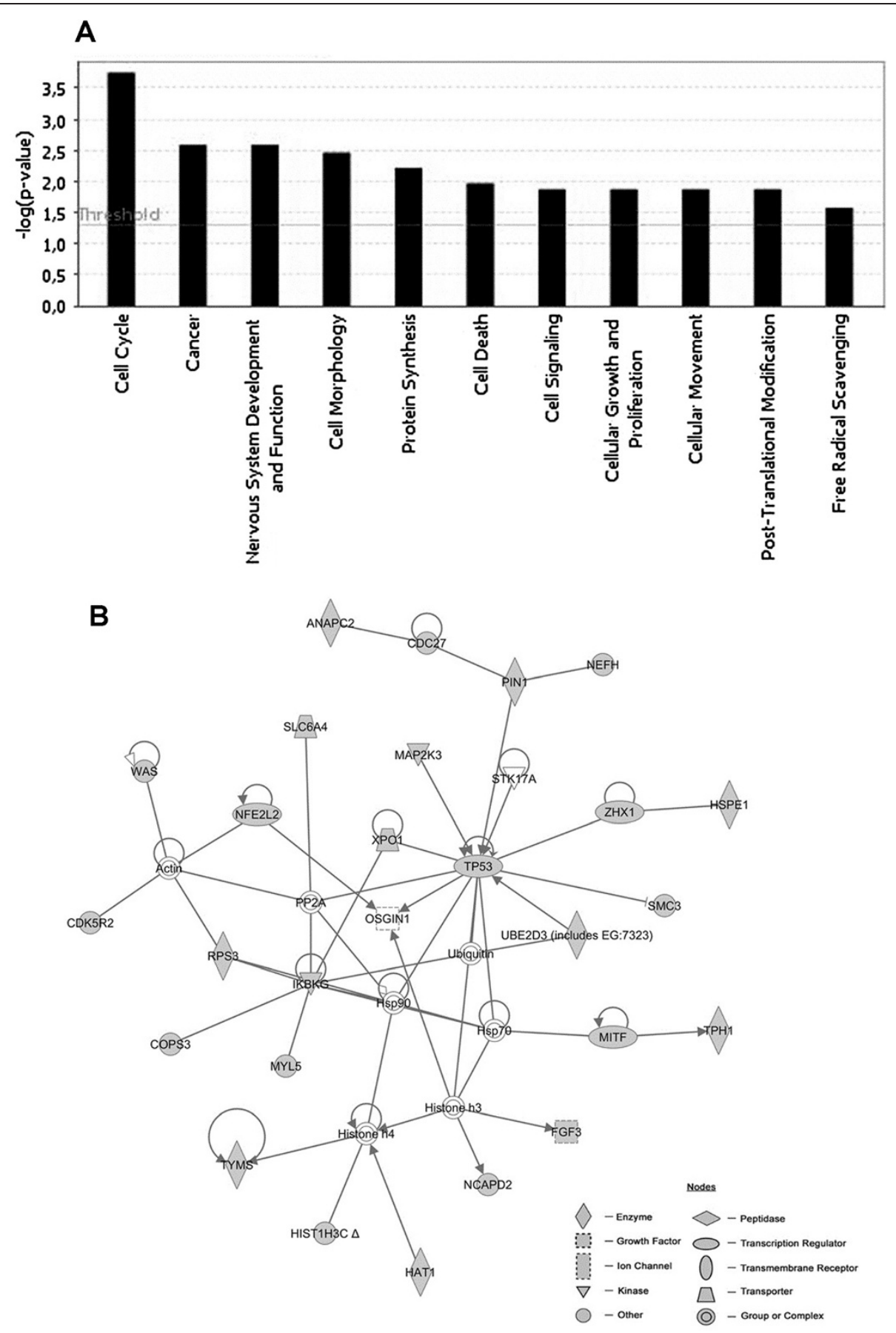

Figure 4 IPA functional analysis and first top network associated with the Cluster 2. (A) Bar chart shows key function associated with genes found to be down-regulated (cluster 2) at the $12^{\text {th }}$ passage of WJ-MSCs as compared to cells at the $4^{\text {th }}$ passage. (B) Network cluster 2: in gray are represented the down-regulated genes at the $12^{\text {th }}$ passage of WJ-MSCs in vitro expanded, as compared to the same cells at the $4^{\text {th }}$ passage. Transcripts not modulated along with the different passages are represented in white. Arrows indicate that a molecule acts on another molecule, while lines indicate a bind between two molecules.

process [41,42], probably due to a reduced transcriptional activity [73]. In the present study, the downregulation of the TP53 in older cells was associated to a contemporary down regulation of genes encoding for both transcriptional factors and proteins involved in post-translational modifications, such as UBE2D3, MAP2K3, ZHX1, XPO1, PIN1, CDC27, ANAPC2 [74]. In the same network are also present other genes related to specific cell functions not linked to any evident node gene. Some of these genes, listed in results section, are 
Table 2 Up-regulated gene functions in cell cultures at $12^{\text {th }}$ passage as compared to cells at $4^{\text {th }}$ passage

\begin{tabular}{|c|c|c|c|c|}
\hline Class & Gene & Description & Functions & Ref \\
\hline \multirow[t]{5}{*}{ IL1 NODE } & IL1 & $\begin{array}{l}\text { Pro-inflammatory cytokine } \\
\text { involved in host defense }\end{array}$ & Activation of NF-kappaB; Induction of acute and chronic inflammation & {$[20]$} \\
\hline & IL1B & Cytokine activated by Caspase 1 & Cell proliferation; Cell differentiation; Apoptosis & {$[21]$} \\
\hline & IL1R1 & Cytokine receptor 1 & Immune and inflammatory response & {$[20]$} \\
\hline & S100A13 & $\begin{array}{l}\text { Calcium binding protein induced } \\
\text { by inflammatory stress }\end{array}$ & Cell cycle progression; Cellular differentiation & [22] \\
\hline & TWIST2 & MSCs marker & Negative regulator of IL1B; Cell lineage determination; Cellular differentiation & {$[23,24]$} \\
\hline \multirow[t]{3}{*}{ AKT NODE } & AKT & Protein kinase B & Cellular growth; Mitosis; Cellular differentiation & {$[25]$} \\
\hline & RAC2 & Member of Rho GTPase family & $\begin{array}{l}\text { Proliferation; Cellular differentiation; Cytoskeletal organization; Cellular } \\
\text { adhesion; Membrane trafficking, Transcriptional regulation }\end{array}$ & {$[26,27]$} \\
\hline & PTPRF & $\begin{array}{l}\text { LAR protein tyrosine phosphatase } \\
\text { sigma family }\end{array}$ & Neuronal differentiation; Cellular development & {$[28]$} \\
\hline \multirow{4}{*}{$\begin{array}{l}\text { Transcription } \\
\text { regulators }\end{array}$} & CREBBP & CREB binding protein & Histone acetyltransferase activity; Transcriptional regulation & [29] \\
\hline & PARP1 & Poly (ADP-ribose) polymerase & Cellular proliferation; Cellular differentiation & {$[30]$} \\
\hline & HNRNPAB & $\begin{array}{l}\text { Ribonucleoprotein associated } \\
\text { with pre-mRNAs }\end{array}$ & RNA processing and trafficking; Cellular differentiation & {$[31]$} \\
\hline & NONO & RNA-binding protein & Transcriptional regulation; RNA splicing; RNA retention in nucleus & {$[32]$} \\
\hline \multirow{2}{*}{$\begin{array}{l}\text { Cytoskeleton } \\
\text { organization }\end{array}$} & ACTR3 & Actin-related protein & Neuronal differentiation & [33] \\
\hline & $\mathrm{NISCH}$ & Nischarin & Negative role in cell migration & {$[34]$} \\
\hline \multirow[t]{6}{*}{ Neural markers } & EPHA4 & $\begin{array}{l}\text { Ephrin recepotor of protein- } \\
\text { tyrosine kinase family }\end{array}$ & Nervous system development & [35] \\
\hline & MT2A & Melatonin recepror 2 & Expressed in neural progenitor & [36] \\
\hline & $\mathrm{CDH} 2$ & Cadherin & Cellular differentiation via RAC & {$[37]$} \\
\hline & ERRFI1 & Cytoplasmic protein & Induced by cellular stress; Cell signalling & {$[38]$} \\
\hline & RNF7 & Ring finger protein & Part of protein degradation machinery; Antiapoptotic activity via JUN & {$[39]$} \\
\hline & LYN & $\begin{array}{l}\text { v-yes-1 Yamaguchi sarcoma viral } \\
\text { related oncogene }\end{array}$ & Tyrosine kinase activity; Cellular proliferation & [40] \\
\hline
\end{tabular}

of particular interest for further discussion. The down regulation of genes related to oxidative stress response (RPS3, NFE2L2, HSP1 and HAT1), has been reported to indicate the cell inability to react to oxidative and DNA damage $[59,60,75]$. The reduced capacity in protein folding, related to HSP1 down-expression, causes incapacity to react to stress and accelerates aging process [61-63]. The down-expression of IKBKG and MYL5, involved in NF- $\mathrm{kB}$ signaling [65], can be related to abnormal growth of cells while MITF down-regulation is associated with loss of pluripotency [56]. In the down-expressed dataset are present two genes (HIST1H3C and HAT1) involved in histone modifications. The down expression of HIST1H3C (encoding a member of the histone H3 family) is related to loss of pluripotency and represents a marker of differentiation in stem cells [76]. The highest expression of HAT1 (encoding a protein involved in rapid acetylation of newly synthesized cytoplasmic histones) occurs during embryogenesis and its down expression is related to aging and differentiation processes [68]. Taken together, all data obtained in this study indicate that WJ-MSCs appear to undergo a process of aging rather than senescence during the in vitro expansion from the $4^{\text {th }}$ to the $12^{\text {th }}$ culture passage. In fact, cellular aging can be defined as a progressive decline in the physiological properties of tissues, characterized by a decreased replication capacity and an increase of cell-cycle -arrested cells, while senescence is the state in which cells have irreversibly lost their proliferation ability [41]. This is mainly demonstrated by the observed low frequency of cells staining positive for $\beta$-galactosidase found in all different passages, indicating that even at $12^{\text {th }}$ passage cells cannot be considered as senescent. In addition, further evidences are provided by the presence of intact G1 and G2 cell-cycle checkpoints and by the presence of long telomeric end at all examined passages, which confirm that WJ-MSCs preserve their capability to undergo a high number of cellular divisions up to the $12^{\text {th }}$ passage. Cellular aging can be considered as an evolutionary conserved defence representing an alternative to cell death in the presence of chronic low stress conditions increasing resistance to apoptosis and thus allowing the survival of post-mitotic cells damaged in their central functions. These figures reflects the cell 
Table 3 Down-regulated gene functions in cell cultures at $12^{\text {th }}$ passage as compared to cells at $4^{\text {th }}$ passage

\begin{tabular}{|c|c|c|c|c|}
\hline Class & Gene & Description & Functions & Ref \\
\hline \multirow[t]{8}{*}{ TP53 NODE } & TP53 & Major tumor protein suppressor & Cell cycle; Apoptosis; Senescence & {$[41,42]$} \\
\hline & UBE2D3 & $\begin{array}{l}\text { Member of E2 ubiquitin conjugating } \\
\text { enzyme family }\end{array}$ & Protein degradation machinery & [43] \\
\hline & MAP2K3 & $\begin{array}{l}\text { Protein kinase activated by } \\
\text { environmental stress }\end{array}$ & $\begin{array}{l}\text { Gene expression regulation; Mitosis; Cellular differentiation; } \\
\text { Cellular proliferation; Apoptosis; Senescence }\end{array}$ & {$[44]$} \\
\hline & $\mathrm{ZHX1}$ & $\begin{array}{l}\text { Zing finger and homeoboxes gene } \\
\text { family }\end{array}$ & Maintenance of TP53 gene silencing & {$[45]$} \\
\hline & XPO1 & Exportin 1 & $\begin{array}{c}\text { Protein trafficking; Localization of cyclin b; Localization } \\
\text { of MPAK; Nuclear export of TP53 }\end{array}$ & {$[46]$} \\
\hline & PIN1 & $\begin{array}{l}\text { Phosphorylation-dependent prolyne } \\
\text { isomerase }\end{array}$ & $\begin{array}{l}\text { Cellular differentiation; Cellular proliferation; Immune } \\
\text { response; Mitosis }\end{array}$ & {$[47,48]$} \\
\hline & $\mathrm{CDC} 27$ & $\begin{array}{l}\text { Component of anaphase promoting } \\
\text { complex }\end{array}$ & Mitosis; Ubiquitination & {$[49]$} \\
\hline & ANAPC2 & Anaphase promoting complex & Cell cycle control; Ubiquitination & {$[50]$} \\
\hline \multirow{4}{*}{$\begin{array}{l}\text { Cell cycle regulation and } \\
\text { differentiation }\end{array}$} & TYMS & Thymidylate syntase & DNA replication and repair; Mitosis & {$[51]$} \\
\hline & FGFR3 & Fibroblast growth factor receptor 3 & Mitosis; MSCs differentiation & {$[52,53]$} \\
\hline & NCAPD2 & Subunit of condensin I & Mitosis; Proliferation & {$[54,55]$} \\
\hline & MITF & Transcription factor & Cell cycle regulation; Gene expression; Differentiation & {$[56-58]$} \\
\hline \multirow[t]{3}{*}{ Oxidative stress response } & RPS3 & Ribosomal protein (40s subunit) & DNA damage repair; Kinase activity on NFkB complex & [59] \\
\hline & NFE2L2 & $\begin{array}{l}\text { Human basic leucine zipper } \\
\text { transcription factor }\end{array}$ & Oxidative stress response & {$[60]$} \\
\hline & HSP1 & Heat-shock protein 1 & Protein folding & {$[61-63]$} \\
\hline \multirow[t]{2}{*}{ NFkB signalling } & IKBKG & Regulatory subunit of IKK complex & NFkB activation & {$[64]$} \\
\hline & MYL5 & Myosin light chain & NFkB activation & {$[65,66]$} \\
\hline Apoptosis & SLC6A4 & Membrane serotonin transporter & Apoptosis & {$[67]$} \\
\hline \multirow[t]{2}{*}{ Histonic modification } & HAT1 & Histone acetyltransferase B & Histone acetylation; Aging; Cellular differentiation & [68] \\
\hline & HIST1H3C & Member of Histone $\mathrm{H} 3$ family & Transcriptional regulation; Cellular differentiation & {$[69]$} \\
\hline
\end{tabular}

biological condition and confirms previously reported data about the presence of an aging phenotype of these cells as evidenced by proteomic analysis [15]. Salminen et al. [41], have recently described that the molecular basis of increased resistance to apoptosis in aging cells involves several mechanisms such as alterations in p53 and NF- $\mathrm{KB}$ networks and pathways, protein folding, and increased presence of pro-inflammatory mediators. Our results match with these mechanisms, demonstrating a resistance to apoptosis related to the above described down-expression of $\mathrm{p} 53$ and the over-expression of TWIST2, RNF7 and ILB1 genes, present in the first top network, as well as of SOD2, RPS27L and STAMBP genes, included in the up-expressed gene cluster. TWIST2 and ILB1 are able to induce the resistance to apoptosis mediated by NF- $\mathrm{KB}$ [77], which activates antiapoptotic survival genes such as SOD2, the cytokine STAMBP, and the caspase activator RPS27L, all positive regulator of anti-apoptotic signaling acting on different pathways. Feng et al. [74], convincingly demonstrated that the functional activity of p53 declines in several murine tissues during aging. Moreover, a reduced capacity in protein folding is related to apoptosis and cell death. Aging process and incapacity to react to stress are also related to down expression of the NFE2L2-NFE2-NFE2L gene complex [60]. The resistance to apoptosis is also enhanced by persistent type of stress, e.g. oxidative stress [41] and in this view, our data show the over-expression of IL1B, LTBP1 AND RAC2 genes, related to the production of oxidative species. The aging process denotes a reduced capacity to maintain intact cytoskeleton structures, affecting cellular processes such as motility, interaction with neighbouring cells and mitosis [34], and in the present study, we demonstrated the over-expression in older cells of NISCH gene. ACTR3 instead is demonstrated to be upregulated during stem cell differentiation [33], in particular the neural differentiation. Moreover, as confirmed by data from cell cultures, the cells at the $12^{\text {th }}$ passage show decreased proliferation likely related to the above described down-expression of genes such as MAP2K3, PIN1, CDC27, ANAPC2, TYMS, FGFR3, NCAPD2, MYL5. The same cells also show altered modulation of HIST1H3C, PTPRF, EPHA4, MT2A, CDK5R2, CDH2, 


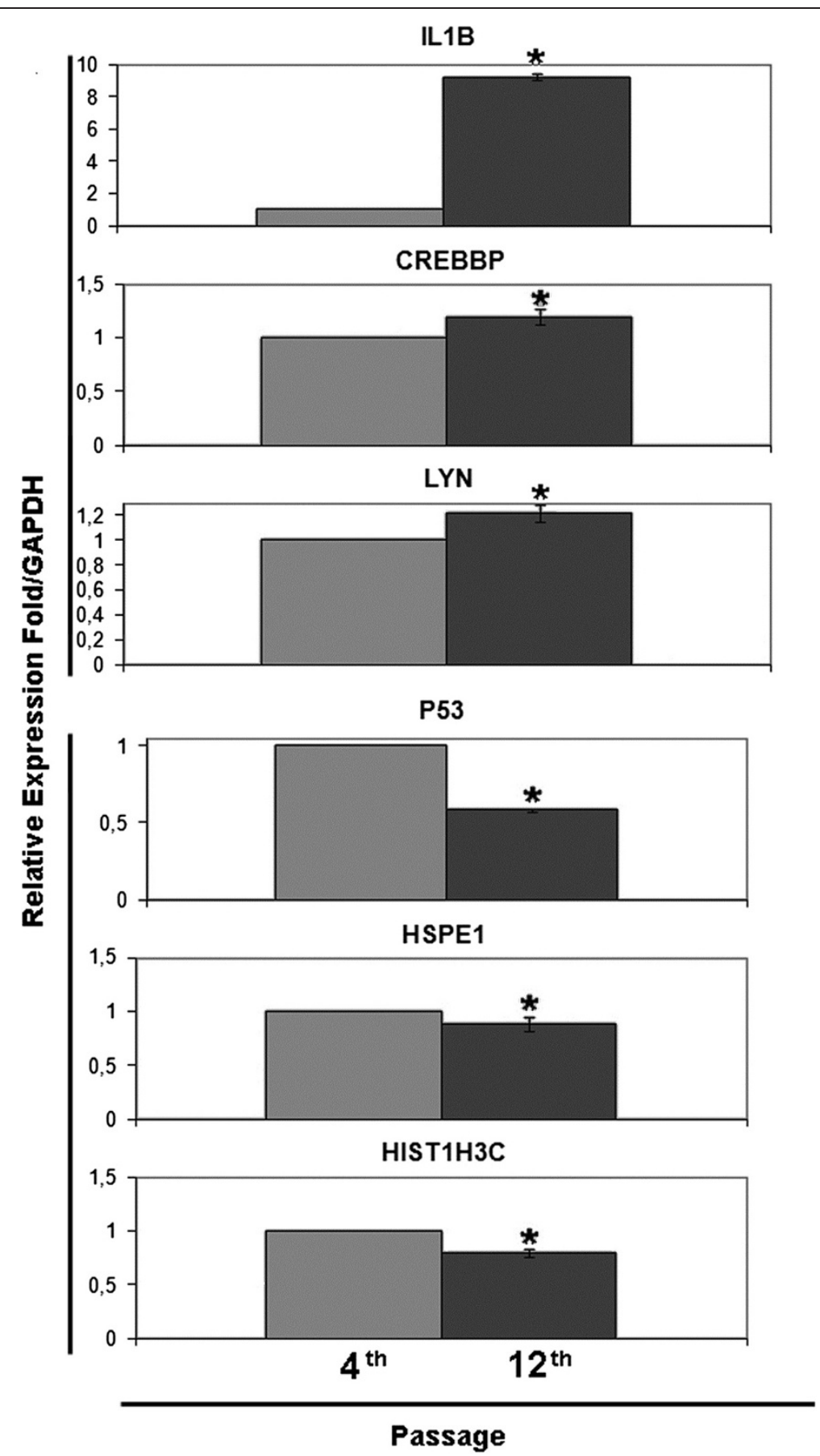

Figure $\mathbf{5}$ Validation microarray gene expression data by qRT-PCR. Analysis of the selected genes IL1B, CREBBP, LYN, P53, HSPE1, HIST1H3C was carried on the RNA obtained by $4^{\text {th }}$ and $12^{\text {th }}$ passage of WJ-MSCs. Data are the means \pm SD of three independent experiments in triplicate $\left({ }^{*} P<0.01\right.$, Student's t-test)

genes related to neuronal differentiation indicating a loss in WJ-MSCs plasticity.

\section{Conclusion}

In conclusion, data provided by cell culture experiments and results obtained by profiling studies, all together demonstrate the impairment WJ-MSCs expansion abilities and their resistance to apoptosis, two hallmarks of cell aging. On the other hand, all these data show the need to develop novel culture protocols able to preserve stem cell plasticity. Moreover, the genes identified as impaired in the present study, could be useful biomarkers 
to evaluate cell culture quality when comparing different in vitro expansion methods.

\section{Availability of supporting data}

Raw data of the performed microarray experiments have been recorded in the GEO public database (accession number: GSE34929).

\section{Additional file}

Additional file 1: Figure S1. Flow cytometric analyses of surface markers at $4^{\text {th }}$ and $12^{\text {th }}$ passage of WJ-MSC. Flow cytometric analysis of WJ-MSCs surface antigen expression profile: CD13, CD14, CD29, CD34, CD44, CD45, CD73, CD90, CD105, CD117 CD133, CD146, CD166, HLA-ABC and HLA-DR Filled histograms represent cells stained with the expression markers; empty histograms show the respective lgG isotype controls. Data are representative of five separate biological samples.

Additional file 2: Figure S2. Flow cytometric analysis of WJ-MSC doubling time and cell cycle. Representative flow cytometric analysis of WJ-MSC doubling time, evaluated by the BrdU incorporation assay (A) and WJ-MSC cell cycle profile obtained by the PI staining only (B). Data are representative of five separate biological samples.

Additional file 3: Table S1. List of transcripts resulting up-expressed in the cluster 1.

Additional file 4: Table S2. List of transcripts resulting down-expressed in the cluster 2.

Additional file 5: Figure S3. Western blot analysis. The intensity of immune-reactivity bands (10 $\mu \mathrm{g}$ of protein) of HIST1H3C, P53 and IL1 $\beta$ was measured by densitometry analysis, normalized respect to the corresponding $\beta$-Actin bands and expressed as arbitrary units (A.U.) (bottom histograms). Data are expressed as the averages \pm SD of three independent experiments.

Additional file 6: Western Blot Method.

\section{Competing interests}

No competing financial interests exist.

\section{Authors' contributions}

VG participated in the design of the study and performed the assembly of data, data analysis and interpretation and drafted the manuscript. MDA participated in assembly of data, microarray experiments, manuscript writing. PL performed cell isolation and culture and telomere length assay. LP performed cell isolation and culture and cell differentiation experiments. SS carried out microarray experiments and participated in assembly of data. GP participated to data analysis and interpretation. MG participated to data analysis and interpretation. MM conceived of the study and participated to samples collection and data interpretation. SM participated in study design and coordination and revising the manuscript critically for important intellectual content. LS participated in study design and coordination, data interpretation and helped to final approval of the manuscript. All authors read and approved the final manuscript.

\section{Authors' information}

Sebastiano Miscia and Liborio Stuppia senior investigators contributed equally to this work.

\section{Acknowledgements}

This work was supported by "Carichieti" foundation, Chieti, Italy and by Italian Ministry of Education, University and Research (MIUR): Co-funding research projects of national interest (COFIN) 2009 Grant and FIRB 2010 "accordi di programma".

\section{Author details}

'Department of Psychological, Humanities and Territory Sciences, School of Medicine and Health Sciences, University "G. d'Annunzio" Chieti-Pescara, via dei Vestini 31,66013 , Chieti, Italy. ${ }^{2}$ Department of Neuroscience and Imaging,
School of Medicine and Health Sciences, University "G. d'Annunzio" ChietiPescara, via dei Vestini 31, 66013, Chieti, Italy. ${ }^{3}$ Department of Medicine and Aging Science, School of Medicine and Health Sciences, University "G. d'Annunzio" Chieti-Pescara, via dei Vestini 31, 66013, Chieti, Italy. ${ }^{4}$ Department of Oral Health and Biotechnological Sciences, School of Medicine and Health Sciences, University "G. d'Annunzio" Chieti-Pescara, via dei Vestini 31, 66013, Chieti, Italy. ${ }^{5}$ StemTeCh Group, via Polacchi 13, 66013 , Chieti, Italy. ${ }^{6}$ Aging Research Center, "Università G. d'Annunzio" Foundation, Via dei Vestini 31, 66013, Chieti, Italy. "Department of Translational Research and New Technologies in Medicine and Surgery, University of Pisa, via Risorgimento 36, 56126, Pisa, Italy.

Received: 4 January 2013 Accepted: 17 September 2013 Published: 21 September 2013

\section{References}

1. Holden C: Versatile stem cells without the ethical baggage? Science 2007, 315(5809):170

2. Hoerstrup SP, Kadner A, Breymann C, Maurus CF, Guenter Cl, Sodian R, Visjager JF, Zund G, Turina MI: Living, autologous pulmonary artery conduits tissue engineered from human umbilical cord cells. Ann Thorac Surg 2002, 74(1):46-52.

3. Grinnemo KH, Månsson A, Dellgren G, Klingberg D, Wardell E, Drvota V, Tammik C, Holgersson J, Ringdén O, Sylvén C, Le Blanc K: Xenoreactivity and engraftment of human mesenchymal stem cells transplanted into infarcted rat myocardium. J Thorac Cardiovasc Surg 2004, 127(5):1293-1300.

4. Lund RD, Wang S, Lu B, Girman S, Holmes T, Sauvé Y, Messina DJ, Harris IR, Kihm AJ, Harmon AM, Chin FY, Gosiewska A, Mistry SK: Cells isolated from umbilical cord tissue rescue photoreceptors and visual functions in a rodent model of retinal disease. Stem Cells 2007, 25(3):602-11.

5. Jomura S, Uy M, Mitchell K, Dallasen R, Bode CJ, Xu Y: Potential treatment of cerebral global ischemia with Oct-4+ umbilical cord matrix cells. Stem Cells 2007, 25(1):98-106.

6. Gandia C, Armiñan A, García-Verdugo JM, Lledó E, Ruiz A, Miñana MD, Sanchez-Torrijos J, Payá R, Mirabet V, Carbonell-Uberos F, Llop M, Montero JA, Sepúlveda P: Human dental pulp stem cells improve left ventricular function, induce angiogenesis, and reduce infarct size in rats with acute myocardial infarction. Stem Cells 2008, 26(3):638-45.

7. Volponi AA, Pang Y, Sharpe PT: Stem cell-based biological tooth repair and regeneration. Trends Cell Biol 2012, 20(12):715-22.

8. Chamberlain G, Fox J, Ashton B, Middleton J: Mesenchymal stem cells: their phenotype, differentiation capacity, immunological features, and potential for homing. Stem Cells 2007, 25(11):2739-49.

9. Kolf CM, Cho E, Tuan RS: Mesenchymal stromal cells. Biology of adult mesenchymal stem cells: regulation of niche, self-renewal and differentiation. Arthritis Res Ther 2007, 9(1):204

10. Romanov YA, Svintsitskaya VA, Smirnov VN: Searching for alternative sources of postnatal human mesenchymal stem cells: candidate MSClike cells from umbilical cord. Stem Cells 2003, 21(1):105-10.

11. Miao Z, Jin J, Chen L, Zhu J, Huang W, Zhao J, Qian H, Zhang X: Isolation of mesenchymal stem cells from human placenta: comparison with human bone marrow mesenchymal stem cells. Cell Biol Int 2006, 30(9):681-7.

12. Csaki C, Matis U, Mobasheri A, Ye H, Shakibaei M: Chondrogenesis, osteogenesis and adipogenesis of canine mesenchymal stem cells: a biochemical, morphological and ultrastructural study. Histochem Cell Biol 2007, 128(6):507-20

13. Wang HS, Hung SC, Peng ST, Huang CC, Wei HM, Guo YJ, Fu YS, Lai MC, Chen CC: Mesenchymal stem cells in the Wharton's jelly of the human umbilical cord. Stem Cells 2004, 22(7):1330-7.

14. Hsieh JY, Fu YS, Chang SJ, Tsuang YH, Wang HW: Functional module analysis reveals differential osteogenic and stemness potentials in human mesenchymal stem cells from bone marrow and Wharton's jelly of umbilical cord. Stem Cells Dev 2010, 19(12):1895-910.

15. Angelucci S, Marchisio M, Di Giuseppe F, Pierdomenico L, Sulpizio M, Eleuterio E, Lanuti P, Sabatino G, Miscia S, Di Ilio C: Proteome analysis of human Wharton's jelly cells during in vitro expansion. Proc Natl Acad Sci USA 2010, 8:18.

16. Lanuti P, Fuhrmann S, Lachmann R, Marchisio M, Miscia S, Kern F: Simultaneous characterization of phospho-proteins and cell cycle in activated T cell subsets. Int J Immunopathol Pharmacol 2009, 22(3):689-98. 
17. Lanuti P, Marchisio M, Cantilena S, Paludi M, Bascelli A, Gaspari AR, Grifone G, Centurione MA, Papa S, Di Pietro R, Cataldi A, Miscia S, Bertagnolo V: A flow cytometry procedure for simultaneous characterization of cell DNA content and expression of intracellular protein kinase C-zeta. J Immunol Methods 2006, 315(1-2):37-48.

18. Gatta V, Raicu F, Ferlin A, Antonucci I, Scioletti AP, Garolla A, Palka G, Foresta C, Stuppia L: Testis transcriptome analysis in male infertility: new insight on the pathogenesis of oligo-azoospermia in cases with and without AZFc microdeletion. BMC Genomics 2010, 11:401.

19. Livak KJ, Schmittgen TD: Analysis of relative gene expression data using real-time quantitative PCR and the 2(-Delta Delta C(T)) Method. Methods 2001, 25(4):402-8.

20. Normand S, Massonnet B, Delwail A, Favot L, Cuisset L, Grateau G, Morel F, Silvain C, Lecron JC: Specific increase in caspase- 1 activity and secretion of IL-1 family cytokines: a putative link between mevalonate kinase deficiency and inflammation. Eur Cytokine Netw 2009, 20(3):101-7.

21. Schwarznau A, Hanson MS, Sperger JM, Schram BR, Danobeitia JS, Greenwood KK, Vijayan A, Fernandez LA: IL-1 beta receptor blockade protects islets against pro-inflammatory cytokine induced necrosis and apoptosis. J Cell Physiol 2009, 220(2):341-7.

22. McLachlan JL, Sloan AJ, Smith AJ, Landini G, Cooper PR: S100 and cytokine expression in caries. Infect Immun 2004, 72(7):4102-8.

23. Šošić D, Richardson JA, Yu K, Ornitz DM, Olson EN: Twist regulates cytokine gene expression through a negative feedback loop that represses NF-kappaB activity. Cell 2003, 112(2):169-80.

24. Kanematsu D, Shofuda T, Yamamoto A, Ban C, Ueda T, Yamasaki M, Kanemura $Y$ : Isolation and cellular properties of mesenchymal cells derived from the decidua of human term placenta. Differentiation 2011, 82(2):77-88

25. Ma FX, Han ZC: Akt signaling and its role in postnatal neovascularization. Histol Histopathol 2005, 20(1):275-81.

26. Gu Y, Byrne MC, Paranavitana NC, Aronow B, Siefring JE, D'Souza M, Horton HF, Quilliam LA, Williams DA: Rac2, a hematopoiesis-specific Rho GTPase, specifically regulates mast cell protease gene expression in bone marrow-derived mast cells. Mol Cell Biol 2002, 22(21):7645-57.

27. Muthukrishnan R, Skalnik DG: Identification of a minimal cis-element and cognate trans-factor(s) required for induction of Rac2 gene expression during K562 cell differentiation. Gene 2009, 440(1-2):63-72.

28. Kim WK, Jung H, Kim DH, Kim EY, Chung JW, Cho YS, Park SG, Park BC, Ko Y, Bae KH, Lee SC: Regulation of adipogenic differentiation by LAR tyrosine phosphatase in human mesenchymal stem cells and 3T3-L1 preadipocytes. J Cell Sci 2009, 122(Pt 22):4160-7.

29. Dworkin S, Malaterre J, Hollande F, Darcy PK, Ramsay RG, Mantamadiotis T: CAMP response element binding protein is required for mouse neural progenitor cell survival and expansion. Stem Cells 2009, 27(6):1347-57.

30. Gao F, Kwon SW, Zhao Y, Jin Y: PARP1 poly(ADP-ribosyl)ates Sox2 to control Sox2 protein levels and FGF4 expression during embryonic stem cell differentiation. J Biol Chem 2009, 284(33):22263-73.

31. Pardo M, Lang B, Yu L, Prosser H, Bradley A, Babu MM, Choudhary J: An expanded Oct4 interaction network: implications for stem cell biology, development, and disease. Cell Stem Cell 2010, 6(4):382-95.

32. Chen LL, Carmichael GG: Altered nuclear retention of mRNAs containing inverted repeats in human embryonic stem cells: functional role of a nuclear noncoding RNA. Mol Cell 2009, 35(4):467-78.

33. Wang D, Gao L: Proteomic analysis of neural differentiation of mouse embryonic stem cells. Proteomics 2005, 5(17):4414-26.

34. Alahari SK, Lee JW, Juliano RL: Nischarin, a novel protein that interacts with the integrin alpha5 subunit and inhibits cell migration. J Cell Biol 2000, 151(6):1141-54

35. North HA, Zhao X, Kolk SM, Clifford MA, Ziskind DM, Donoghue MJ: Promotion of proliferation in the developing cerebral cortex by EphA4 forward signaling. Development 2009, 136(14):2467-76

36. Niles LP, Armstrong KJ, Rincón Castro LM, Dao CV, Sharma R, McMillan CR, Doering LC, Kirkham DL: Neural stem cells express melatonin receptors and neurotrophic factors: colocalization of the MT1 receptor with neuronal and glial markers. BMC Neurosci 2004, 5:41.

37. Gao L, McBeath R, Chen CS: Stem cell shape regulates a chondrogenic versus myogenic fate through Rac1 and N-cadherin. Stem Cells 2010 28(3):564-72.

38. Fiorentino L, Pertica C, Fiorini M, Talora C, Crescenzi M, Castellani L, Alemà S, Benedetti P, Segatto O: Inhibition of ErbB-2 mitogenic and transforming activity by RALT, a mitogen-induced signal transducer which binds to the ErbB-2 kinase domain. Mol Cell Biol 2000, 20(20):7735-50

39. Wick M, Bürger C, Funk M, Müller R: Identification of a novel mitogen-inducible gene (mig-6): regulation during G1 progression and differentiation. Exp Cell Res 1995, 219(2):527-35.

40. Iqbal MS, Tsuyama N, Obata M, Ishikawa H: A novel signaling pathway associated with Lyn, PI 3-kinase and Akt supports the proliferation of myeloma cells. Biochem Biophys Res Commun 2010, 392(3):415-20.

41. Salminen A, Ojala J, Kaarniranta K: Apoptosis and aging: increased resistance to apoptosis enhances the aging process. Cell Mol Life Sci 2011, 68(6):1021-31

42. Zhao T, Xu Y: P53 and stem cells: new developments and new concerns. Trends Cell Biol 2010, 20(3):170-5.

43. Saville MK, Sparks A, Xirodimas DP, Wardrop J, Stevenson LF, Bourdon JC, Woods YL, Lane DP: Regulation of p53 by the ubiquitin-conjugating enzymes UbcH5B/C in vivo. J Biol Chem 2004, 279(40):42169-81.

44. Jia M, Souchelnytskyi N, Hellman U, O'Hare M, Jat PS, Souchelnytskyi S: Proteome profiling of immortalization-to-senescence transition of human breast epithelial cells identified MAP2K3 as a senescencepromoting protein which is downregulated in human breast cancer. Proteomics Clin Appl 2010, 4(10-11):816-28.

45. Kim SH, Park J, Choi MC, Kim HP, Park JH, Jung Y, Lee JH, Oh DY, Im SA, Bang YJ, Kim TY: Zinc-fingers and homeoboxes 1 (ZHX1) binds DNA methyltransferase (DNMT) 3B to enhance DNMT3B-mediated transcriptional repression. Biochem Biophys Res Commun 2007, 355(2):318-23.

46. Lohrum MA, Woods DB, Ludwig RL, Bálint E, Vousden KH: C-terminal ubiquitination of p53 contributes to nuclear export. Mol Cell Biol 2001, 21(24):8521-32.

47. Jentsch S, Siepe D: Pin1, a novel switch in the ubiquitin pathway. Cell Cycle 2009, 8(23):3800-1.

48. Lu KP, Hanes SD, Hunter T: A human peptidyl-prolyl isomerase essential for regulation of mitosis. Nature 1996, 380(6574):544-7.

49. Pawar SA, Sarkar TR, Balamurugan K, Sharan S, Wang J, Zhang Y, Dowdy SF, Huang AM, Sterneck E: C/EBP\{delta\} targets cyclin D1 for proteasomemediated degradation via induction of CDC27/APC3 expression. Proc Natl Acad Sci USA 2010, 107(20):9210-5.

50. Fang G, Yu H, Kirschner MW: The checkpoint protein MAD2 and the mitotic regulator CDC20 form a ternary complex with the anaphasepromoting complex to control anaphase initiation. Genes Dev 1998, 12(12):1871-83.

51. Kokkinakis DM, Liu X, Neuner RD: Modulation of cell cycle and gene expression in pancreatic tumor cell lines by methionine deprivation (methionine stress): implications to the therapy of pancreatic adenocarcinoma. Mol Cancer Ther 2005, 4(9):1338-48.

52. Cohen ED, Wang Z, Lepore JJ, Lu MM, Taketo MM, Epstein DJ, Morrisey EE: Wnt/beta-catenin signaling promotes expansion of Is|-1-positive cardiac progenitor cells through regulation of FGF signaling. J Clin Invest 2007 117(7):1794-804

53. Moore JW, Dionne C, Jaye M, Swain JL: The mRNAs encoding acidic FGF, basic FGF and FGF receptor are coordinately downregulated during myogenic differentiation. Development 1991, 111(3):741-8.

54. Verlinden L, Eelen G, Beullens I, Van Camp M, Van Hummelen P, Engelen K Van Hellemont R, Marchal K, De Moor B, Foijer F, Te Riele H, Beullens M, Bollen M, Mathieu C, Bouillon R, Verstuyf A: Characterization of the condensin component Cnap1 and protein kinase Melk as novel E2F target genes down-regulated by 1,25-dihydroxyvitamin D3. J Biol Chem 2005, 280(45):37319-30.

55. Watrin E, Legagneux V: Contribution of hCAP-D2, a non-SMC subunit of condensin I, to chromosome and chromosomal protein dynamics during mitosis. Mol Cell Biol 2005, 25(2):740-50.

56. Gleason BC, Crum CP, Murphy GF: Expression patterns of MITF during human cutaneous embryogenesis: evidence for bulge epithelial expression and persistence of dermal melanoblasts. J Cutan Pathol 2008, 35(7):615-22.

57. McGill GG, Horstmann M, Widlund HR, Du J, Motyckova G, Nishimura EK, Lin YL, Ramaswamy S, Avery W, Ding HF, Jordan SA, Jackson IJ, Korsmeyer SJ, Golub TR, Fisher DE: Bcl2 regulation by the melanocyte master regulator Mitf modulates lineage survival and melanoma cell viability. Cell 2002, 109(6):707-18

58. Schepsky A, Bruser K, Gunnarsson GJ, Goodall J, Hallsson JH, Goding CR, Steingrimsson $E$, Hecht $A$ : The microphthalmia-associated transcription 
factor Mitf interacts with beta-catenin to determine target gene expression. Mol Cell Biol 2006, 26(23):8914-27.

59. Gao X, Wan F, Mateo K, Callegari E, Wang D, Deng W, Puente J, Li F, Chaussee MS, Finlay BB, Lenardo MJ, Hardwidge PR: Bacterial effector binding to ribosomal protein s3 subverts NF-kappaB function. PLoS Pathog 2009, 5(12):e1000708.

60. Saw CL, Wu Q, Kong AN: Anti-cancer and potential chemopreventive actions of ginseng by activating Nrf2 (NFE2L2) anti-oxidative stress/antiinflammatory pathways. Chin Med 2010, 5:37.

61. Corrao S, Campanella C, Anzalone R, Farina F, Zummo G, Conway de Macario E, Macario AJ, Cappello F, La Rocca G: Human Hsp10 and Early Pregnancy Factor (EPF) and their relationship and involvement in cancer and immunity: current knowledge and perspectives. Life Sci 2010, 86(5-6):145-52.

62. Tazir Y, Steisslinger V, Soblik H, Younis AE, Beckmann S, Grevelding CG, Steen H, Brattig NW, Erttmann KD: Molecular and functional characterisation of the heat shock protein 10 of strongyloides ratti. Mol Biochem Parasitol 2009, 168(2):149-57.

63. Walsh A, Whelan D, Bielanowicz A, Skinner B, Aitken RJ, O'Bryan MK, Nixon $B$ : Identification of the molecular chaperone, heat shock protein 1 (chaperonin 10), in the reproductive tract and in capacitating spermatozoa in the male mouse. Biol Reprod 2008, 78(6):983-93.

64. Ivins FJ, Montgomery MG, Smith SJ, Morris-Davies AC, Taylor IA, Rittinger K: NEMO oligomerization and its ubiquitin-binding properties. Biochem $J$ 2009, 421(2):243-51.

65. Santos M, Moura RS, Gonzaga S, Nogueira-Silva C, Ohlmeier S, Correia-Pinto $\mathrm{J}$ : Embryonic essential myosin light chain regulates fetal lung development in rats. Am J Respir Cell Mol Biol 2007, 37(3):330-8.

66. Fenner BJ, Scannell M, Prehn JH: Expanding the substantial interactome of NEMO using protein microarrays. PLoS One 2010, 5(1):e8799.

67. Serafeim A, Holder MJ, Grafton G, Chamba A, Drayson MT, Luong QT, Bunce $C M$, Gregory CD, Barnes NM, Gordon J: Selective serotonin reuptake inhibitors directly signal for apoptosis in biopsy-like Burkitt lymphoma cells. Blood 2003, 101(8):3212-9.

68. McGraw S, Robert C, Massicotte L, Sirard MA: Quantification of histone acetyltransferase and histone deacetylase transcripts during early bovine embryo development. Biol Reprod 2003, 68(2):383-9.

69. Barman HK, Takami Y, Ono T, Nishijima H, Sanematsu F, Shibahara K, Nakayama T: Histone acetyltransferase 1 is dispensable for replicationcoupled chromatin assembly but contributes to recover DNA damages created following replication blockage in vertebrate cells. Biochem Biophys Res Commun 2006, 345(4):1547-57.

70. Zeng X: Human embryonic stem cells: mechanisms to escape replicative senescences? Sten Cell Rev 2007, 3(4):270-9.

71. Wagner $W$, Ho AD, Zenke M: Different facets of aging in human mesenchymal stem cells. Tissue Eng Part B Rev 2010, 16(4):445-53.

72. Makkinje A, Quinn DA, Chen A, Cadilla CL, Force T, Bonventre JV, Kyriakis JM: Gene 33/Mig-6, a transcriptionally inducible adapter protein that binds GTP-Cdc42 and activates SAPKJJNK. A potential marker transcript for chronic pathologic conditions, such as diabetic nephropathy. Possible role in the response to persistent stress. J Biol Chem 2000, 275(23):17838-47.

73. Kobayashi T, Wang T, Maezawa M, Kobayashi M, Ohnishi S, Hatanaka K, Hige S, Shimizu Y, Kato M, Asaka M, Tanaka J, Imamura M, Hasegawa K, Tanaka Y, Brachmann RK: Overexpression of the oncoprotein prothymosin alpha triggers a p53 response that involves p53 acetylation. Cancer Res 2006, 66(6):3137-44

74. Feng Z, Hu W, Rajagopal G, Levine AJ: The tumor suppressor p53: cancer and aging. Cell Cycle 2008, 7(7):842-7.

75. Bowie A, O'Neill LA: Oxidative stress and nuclear factor-kappaB activation: a reassessment of the evidence in the light of recent discoveries. Biochem Pharmacol 2000, 59(1):13-23.

76. Lessard JA, Crabtree GR: Chromatin regulatory mechanisms in pluripotency. Annu Rev Cell Dev Biol 2010, 26:503-32.

77. Karin M: NF-kappaB as a critical link between inflammation and cancer. Cold Spring Harb Perspect Biol 2009, 1(5):a000141.

doi:10.1186/1471-2164-14-635

Cite this article as: Gatta et al:: Gene expression modifications in Wharton's Jelly mesenchymal stem cells promoted by prolonged in vitro culturing. BMC Genomics 2013 14:635.

\section{Submit your next manuscript to BioMed Central and take full advantage of:}

- Convenient online submission

- Thorough peer review

- No space constraints or color figure charges

- Immediate publication on acceptance

- Inclusion in PubMed, CAS, Scopus and Google Scholar

- Research which is freely available for redistribution 